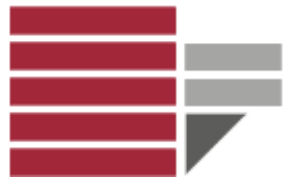

Working Paper n. 02 - 2016

\title{
EXPLORING THE RELATIONSHIP BETWEEN UNIVERSITY AND INNOVATION: EVIDENCE FROM THE ITALIAN FOOD INDUSTRY
}

Paola Cardamone

Dipartimento di Economia,

Statistica e Finanza

Università della Calabria

Ponte Pietro Bucci, Cubo 0/C

Tel.: +390984 492442

Fax: +390984 492421

e-mail: paola.cardamone@unical.it
Valeria Pupo

Dipartimento di Economia,

Statistica e Finanza

Università della Calabria

Ponte Pietro Bucci, Cubo 0/C

Tel.: +390984 492456

Fax: +390984 492421

e-mail: valeria.pupo@unical.it

Fernanda Ricotta

Dipartimento di Economia,

Statistica e Finanza

Università della Calabria

Ponte Pietro Bucci, Cubo 0/C

Tel.: +390984 492407

Fax: +390984 492421

e-mail: fernanda.ricotta@unical.it

\section{Febbraio 2016}

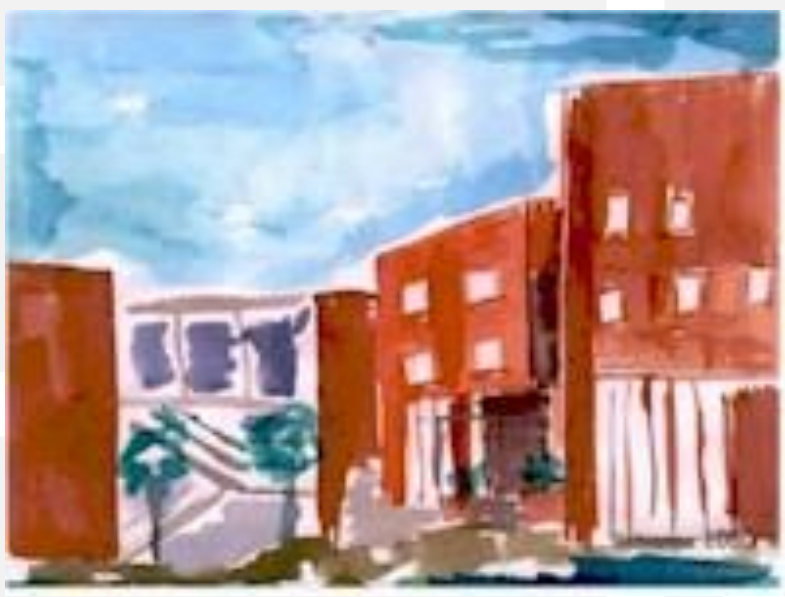




\title{
Exploring the relationship between university and innovation: evidence from the Italian Food Industry
}

\author{
Cardamone P., Pupo V., Ricotta F. \\ (paola.cardamone@unical.it; valeria.pupo@unical.it; fernanda.ricotta@unical.it) \\ Department of Economics, Statistics and Finance, \\ University of Calabria, Arcavacata di Rende (CS), Italy
}

\begin{abstract}
This study provides empirical evidence on the role of universities' Technological Transfer (TT) activities in the Italian manufacturing sector, with particular attention to the food industry. By using the UniCredit-Capitalia database (2008) for firms and data from the Ministry of Education, University and Research (MIUR) to obtain the university TT indicator, we estimate a probit model to assess the effect of universities' TT activities on a firm's likelihood to innovate. Results show that university TT activities seem to stimulate food industry firms innovation and the impact appears significantly higher than for the manufacturing sector.
\end{abstract}

Keywords: Universities, Technology transfer, Food firms, Innovation, Spillovers JEL Classification codes: O30; C25, D22

\section{INTRODUCTION}

Most empirical studies have analysed the behaviour of innovation in manufacturing firms by focusing on high-tech industries, while less attention has been given to knowledge sourcing activities in traditional industries and low-tech sectors. The lack of interest in studying this sector is due to the fact that mature industries generally invest little in $R \& D$ and have low levels of human capital, give importance to incremental innovations around existing products and processes, and depend greatly on specialised suppliers of embodied technologies. These characteristics have meant that there has been a tendency to understate the importance of innovation in these industries (Robertson et al, 2009; Hirsch-Kreinsen, 2008).

The last few years have seen the emergence of a rich vein of literature which has led to a reconsideration of the role that traditional sectors play in modern economies and enhanced our understanding of the importance of innovation and technological change outside R\&D-intensive fields (Robertson et al, 2009). However, there remains a lack of empirically tested research into the relationship between university and innovation in low- and medium-tech sectors and, in the case of the food sector, papers that have empirically analysed this link are particularly rare.

Indeed, the existing literature on the topic shows a positive effect of university research on firms' innovative activity, but focuses mainly on high-tech sectors or manufacturing as a whole (among others, Arvanitis et al, 2008; Fritsch and Franke, 2004; Cardamone et al, 2015; Monjon and Waelbroeck, 2003; Lööf and Broström, 2008 for Sweden; Robin and Schubert, 2013; Eom and Lee, 2010; Belderbos et al, 2004). 
It is very important to develop specific analyses which take the special needs and conditions of mature sectors like the food sector into account, because a strategy of collaboration with public research organisations could also allow firms in the traditional sector to increase their innovative capabilities and strengthen their international competitiveness (Hirsch-Kreinsen et al, 2006). Moreover, it is even more interesting to verify whether there are differences in food firms' innovative behaviour compared with the traditional sector or the manufacturing industry as a whole. Indeed, although food is regarded as a supplier dominated sector, food-processing firms are highly dependent on external developments in new areas of science, such as biotechnology, computing, etc., and actively select and combine a wide range of different new techniques and scientific discoveries (Rama, 1996; Christensen et al, 1996). Consequently, we expect that TT activities developed in universities are likely to play a more important role in the food industry in particular rather than in the supplier dominated sector as a whole. Finally, understanding whether food firms' innovative capabilities can be stimulated through university-industry interaction is useful from a broader societal prospective if we consider that the food industry is one of the largest and most important sectors in European manufacturing with great relevance for employment $(15,5 \%$ of the total manufacturing sector) and economic output (14,6\% of turnover) (CIAA, 2014).

We examine the relationship between university and innovation in the Italian food industry for these reasons. In detail, we aim to investigate whether codified forms of universities' technology transfer (TT) activities would improve firms' capability for innovation. We focus on spillovers that result from a formal relationship (patents, spin-off firms and research contracts) because some studies (IPI, 2005; Muscio, 2008) show that there are difficulties in university-firm interaction due to the lack of a consolidated university procedure for collaboration with firms and, more generally, the existence of a cognitive distance between professors and entrepreneurs. The presence of formal TT activities indicates a university which is favourable to the exploitation of research by business, is familiar with the productive system and encourages researchers to cooperate with enterprises. All this may facilitate the industry-university relationship and the transfer of both codified and tacit knowledge.

We use the UniCredit-Capitalia database (2008) for firm data, while we employ data from the Ministry of Education, University and Research (MIUR) to obtain the university indicator which takes into account different forms of institutionalised TT, such as patents, spin-off firms and research contracts. We adopt a probit model and, as well as the internal factors that define the firm's innovative strategy, external factors such as agglomeration and spatial externalities are also taken into account. 
The main result of this paper is that university TT activities support innovation in the food sector, so confirming that food firms benefit more from spillovers from universities than do the "supplier dominated" sector and manufacturing firms as a whole. Indeed, the impact of university TT activities appears significantly higher in the food industry than in the manufacturing sector as a whole, while it is not relevant for the supplier dominated sector.

Our contribution is threefold. First, our study contributes to the literature on the economics of knowledge transfer by highlighting university-industry interaction in a "mature" industry, the food industry, and providing preliminary evidence that certain knowledge transfer mechanisms between university and firms seem to augment the probability to innovate. Second, in comparing the food sector with the traditional sector and manufacturing industry as a whole, we highlight the differences in the innovation behaviour of food firms. Third, we provide an empirical contribution regarding the role of local spatial externalities. To be more precise, we investigate whether TT activities undertaken by universities in provinces other than that in which a firm is located affect that firm's innovativeness.

The remainder of this article is structured as follows: In Section 2, we provide a framework for the analysis of the role of universities in the food industry. Data and the empirical methodology are described in Section 3 and results are presented in Section 4. Section 5 investigates the effect of externalities from technology transfer activities. Finally, we present our main conclusions in Section 6.

\section{INNOVATION AND THE ROLE OF UNIVERSITIES IN THE FOOD INDUSTRY}

This section develops the conceptual framework and reviews the literature on innovation and the role of universities in the food industry.

The relationship between university and industry is receiving increasing attention in both theoretical and empirical literature. The Lisbon agenda (2008) and the EU Report Europe 2020 (European Commission, 2010) stress the important role of active cooperation between firms and universities in maintaining Europe's economic competitiveness. Many works considering a great number of aspects of this debate have been produced in recent years (for a review, see Foray and Lissoni, 2010; Bergman, 2010).

There are the two main strands of literature within our area of analysis. A number of papers have examined the relationship between university and innovation by focusing on the effect of university technology transfer activities, generally proxied by R\&D cooperation, on different measures of innovative performance, such as the propensity to register an innovation for patenting, the number of patent applications, R\&D intensity, the introduction of innovations (product, process and/or 
organisational), and the sales share of innovative products. These studies have found a positive effect of university research on firms' innovative activity (Arvanitis et al, 2008 for Switzerland; Fritsch and Franke, 2004 for Germany; Cardamone et al, 2015 for Italy; Monjon and Waelbroeck, 2003 for France; Lööf and Broström, 2008 for Sweden; Robin and Schubert, 2013 for France and Germany; Eom and Lee, 2010 for Korea; Belderbos et al, 2004 for the Netherlands). A second group of studies has considered the spillover effect of university research by documenting the fact that knowledge spillovers from universities to the private sector tend to be geographically bound to the area where the university is located (among others, see Acs et al 1992, Anselin et al 1997, Jaffe 1989 for the USA; Autant-Bernard, 2001 for France; Audretsch et al 2012, Blind and Grupp, 1999 for Germany; Del Barrio-Castro and García-Quevedo, 2005 for Spain; Leten et al 2011, Piergiovanni et al 1997 for Italy).

The literature on the relationship between university and innovation is extensive and rapidly growing, but research on the food sector is scant. However there are several arguments which claim that science is important in the food industry (Kinsey, 2001; Acosta et al, 2011; Bodas Freitas et al, 2013). The first refers to the characteristics of the food industry. The food industry is classified as low-tech on the basis of low R\&D investment and low levels of human capital. For this reason, it is believed that these firms have low capabilities of innovation and that they mainly focus upon incremental innovations around existing products and processes (Galizzi and Venturini, 1996; Grunert et al, 1997). Therefore, the firms may rely on universities to enlarge their knowledge base, facilitate greater integration of technology with embodied knowledge and support complex problem-solving which relates to the blending of old and new technologies and, consequently, to the development of new processes (Bodas Freitas et al, 2013). The second argument considers the technological environment in which food companies operate, characterised as it is by an extensive range of technologies and new advances in core scientific fields, such as biotechnology (Carew, 2005) and nanotechnology (Chaudhry and Castle, 2011), that offer new opportunities for innovation in the food and related sectors. However, it is not straightforward to integrate complex new technologies into existing processes. In order to exploit all the technological opportunities offered by advances in science, food firms need to interact with a variety of external sources of knowledge, especially research institutions (Menrad, 2004; Avermaete et al, 2004; Sakar and Costa, 2008). ${ }^{1}$ What is more, innovation is an important factor in enhancing competitiveness in the food sector (Menrad, 2004; Capitanio et al 2010; Rama and Von Tunzelmann, 2008) and collaborations with

\footnotetext{
${ }^{1}$ For example, despite an average R\&D investment per worker in Italy that is lower than the average investment of all manufacturers, food firm interaction with the scientific community has also been greater than that of manufacturers as a whole: in the 2006-2008 period, $12.7 \%$ of innovative food firms collaborated with the scientific community compared with an average of $6.5 \%$ for the manufacturing sector (Monducci, 2011).
} 
universities may lead to a greater use of science by firms in support of their innovations. ${ }^{2}$ Finally, topics relating to the food industry constitute an empirically interesting field because it is one of the largest and most important manufacturing sectors in Europe, with great relevance for employment (15,5\% of the total manufacturing sector) and economic output (14,6\% of turnover). The sector accounts for 1,048 billion euro in turnover, 206 billion euro in value added and 4.2 million jobs in the EU-27 (data 2012, see CIAA, 2014). Italy represents the third largest food sector in the European Union, behind just Germany and France (European Commission, 2014). ${ }^{3}$ Therefore, it is useful from a broader societal prospective to understand whether firms' capabilities of innovation can be stimulated through university-industry interactions.

Despite the heavy reliance of food firms on scientific and technological knowledge, as already indicated, papers that have empirically analysed university-food industry links are rare. Indeed, existing literature focuses mainly on high-tech sectors or manufacturing as a whole (among others, Arvanitis et al, 2008; Fritsch and Franke, 2004; Cardamone et al, 2015; Monjon and Waelbroeck, 2003; Lööf and Broström, 2008; Robin and Schubert, 2013; Eom and Lee, 2010; Belderbos et al, 2004) and the few studies that have considered the traditional sectors focus on the differences between low-tech and high-tech industries in terms of their interaction with universities.

For instance, in examining the factors that influence firms' decisions to draw from universities in their innovative activities, Laursen and Salter (2004) find that UK firms in high-tech industries are more likely to interact with universities than firms in low-tech industries. Grimpe and Sofka (2009) confirm this result for European countries and document the fact that companies classified as medium-high and high-technology firms look to suppliers and universities for new knowledge, while low- and medium-low technology firms focus more on customers and competitors. Bodas Freitas et al (2013) provide empirical evidence by highlighting the differences between universityindustry collaboration in Brazil, whose industry can be considered to be both emergent and mature. These studies seem to confirm the idea that universities can only support the innovation in these industries a little. However, results change when the food industry is considered. For example, some recent case studies suggest that food industries use scientific and industrial knowledge to innovate, such as in the case of the wine industry in Chile and South Africa (Giuliani and Rabellotti, 2012)

\footnotetext{
${ }^{2}$ The improvement of competitiveness is particularly important for Italy since the food sector is facing great competition from emerging countries, essentially due to lower labour costs and the greater market penetration capacity of the products of other advanced countries, based chiefly on a more efficient production and marketing structure (Capitanio et al, 2010).

${ }^{3}$ This sector is relevant for the Italian economy since it is the fourth most important sector in terms of value added (11.88\% of the whole manufacturing sector, $€ 24$ billion in 2012), accounts for about 60,000 firms and 430,000 employees, respectively, $13.9 \%$ and $11 \%$ of the whole manufacturing sector (Italian National Statistics InstituteISTAT, 2014).
} 
and in Chile and Italy (Giuliani and Arza, 2009). Giuliani and Rabellotti (2012) explore how universities connect international science with domestic industry and find that this connection occurs through a few 'bridging researchers', those who publish more in international journals and/or have received awards for their academic work. By combining case-study methodology with econometric techniques, Giuliani and Arza (2009) explore the factors that influence the formation of 'valuable university-industry linkages', conceived as those links between universities and firms that have a high potential to diffuse knowledge to other firms in their regional economy. The firm's knowledge base is found to be a key driver of 'valuable' university-industry links. Similar results have been found for Spain (Acosta et al, 2011 and Arias-Aranda and Romerosa-Martínez, 2010). Acosta et al (2011) analyse the factors that influence the use of scientific knowledge in patented technology by agrifood firms in Spain and show that collaboration with universities and firms' technological characteristics are the determining factors in this process. This result is confirmed by Arias-Aranda and Romerosa-Martínez (2010), who consider the relationship between public sector research and industrial development in the functional foods sector in Andalusia and show that public sector support for $R \& D$ combined with high quality academic research encourages the private sector to invest on a local basis. Again with regard the role of public policy, Mckelvey (2014) presents a case study of a policy initiative for collaborative research between universities and industry in Sweden and finds a positive effect on firm capability to innovate. As for Italy, only two studies analyse the relationship between university and the food industry. Muscio and Nardone (2012) investigate the determinants of university-industry collaboration from the university viewpoint and, therefore, they have different objectives from ours. Maietta (2015) examines the determinants of university-firm R\&D collaboration and its impact on product and process innovation and shows that university-firm R\&D collaboration affects process innovation. Product innovation is instead affected positively by geographical proximity to a university and negatively by the level of its codified knowledge production, as measured by the number of citations in ISIScopus indexed journals.

\section{EMPIRICAL ANALYSIS}

\subsection{Description of the data}

This paragraph presents the firm level data used in the empirical analysis. Our firm-level data come from the Xth UniCredit-Capitalia survey (2008), which covers the 2004-2006 period and is compiled on the basis of information collected by means of a questionnaire sent to a sample of 
Italian manufacturing firms. ${ }^{4}$ The survey is integrated with balance sheet data drawn from the Van Dijk Bureau-managed Aida database, from which 1998-2006 balance sheet information is retrieved for each firm surveyed. Table 1 reports the distribution of our sample broken down into innovative and non-innovative firms in the food, traditional sector and manufacturing sector. We consider any firm that claimed, in the Xth wave of the UniCredit-Capitalia survey, to have carried out at least one innovation (product, process or organisational innovation) in the 2004-2006 period as being innovative. $^{5}$

The values are reported on the basis of some firm characteristics, such as Pavitt sector, territorial distribution and size. The firms considered operate predominantly in traditional sectors, are mainly located in Northern Italy (around 72\%, 67\% and 57\% for the manufacturing, traditional and food sectors, respectively) and are mainly SMEs (Small and Medium Enterprises) (around 69\%, 71\% and $74 \%$ for the manufacturing, traditional and food sectors, respectively).

Innovative firms make up $67 \%$ of the total sample $(2,497$ out of 3,719 firms $)$ and $61 \%$ for the food sector (185 out of 301 firms). If we consider the total manufacturing sector, we find that innovators are concentrated in the specialised suppliers and science based Pavitt sectors $(72 \%$ and $77 \%$ respectively). As regards the distribution of innovative firms by area, the highest percentage of innovators is observed in the Centre of the country (about $65 \%$ for the food, $69 \%$ for traditional and $72 \%$ for total manufacturing sectors). Moreover, a higher share is observed for medium-large firms (with a percentage of innovative firms of $66 \%$ in the case of the food sector, $71 \%$ for the traditional sector and $75 \%$ for total manufacturing industry). As for comparisons between the food, traditional and total manufacturing sectors, we find a much larger percentage of southern firms and a higher share of small firms in the food sector than in the traditional and manufacturing industry.

\footnotetext{
${ }^{4}$ The survey design includes all firms with a minimum of 500 employees. A sample of firms with between 11 and 500 employees is selected according to three stratifications: geographical area, Pavitt sector and firm size. Although the survey covers the 2004-2006 period, some parts of the questionnaire refer to 2006 only.

${ }^{5}$ A product innovation is defined as the introduction of a completely new product or an important improvement in an old product at the firm-level. A process innovation refers to the adoption of at least one new or improved process. An organisational innovation regards the introduction of technical organisational innovations relating to products (e.g. the involvement of employees in finding a solution to defective products) and production process (e.g. rearrangement of jobs).
} 
Table 1. Distribution of sample (2006)

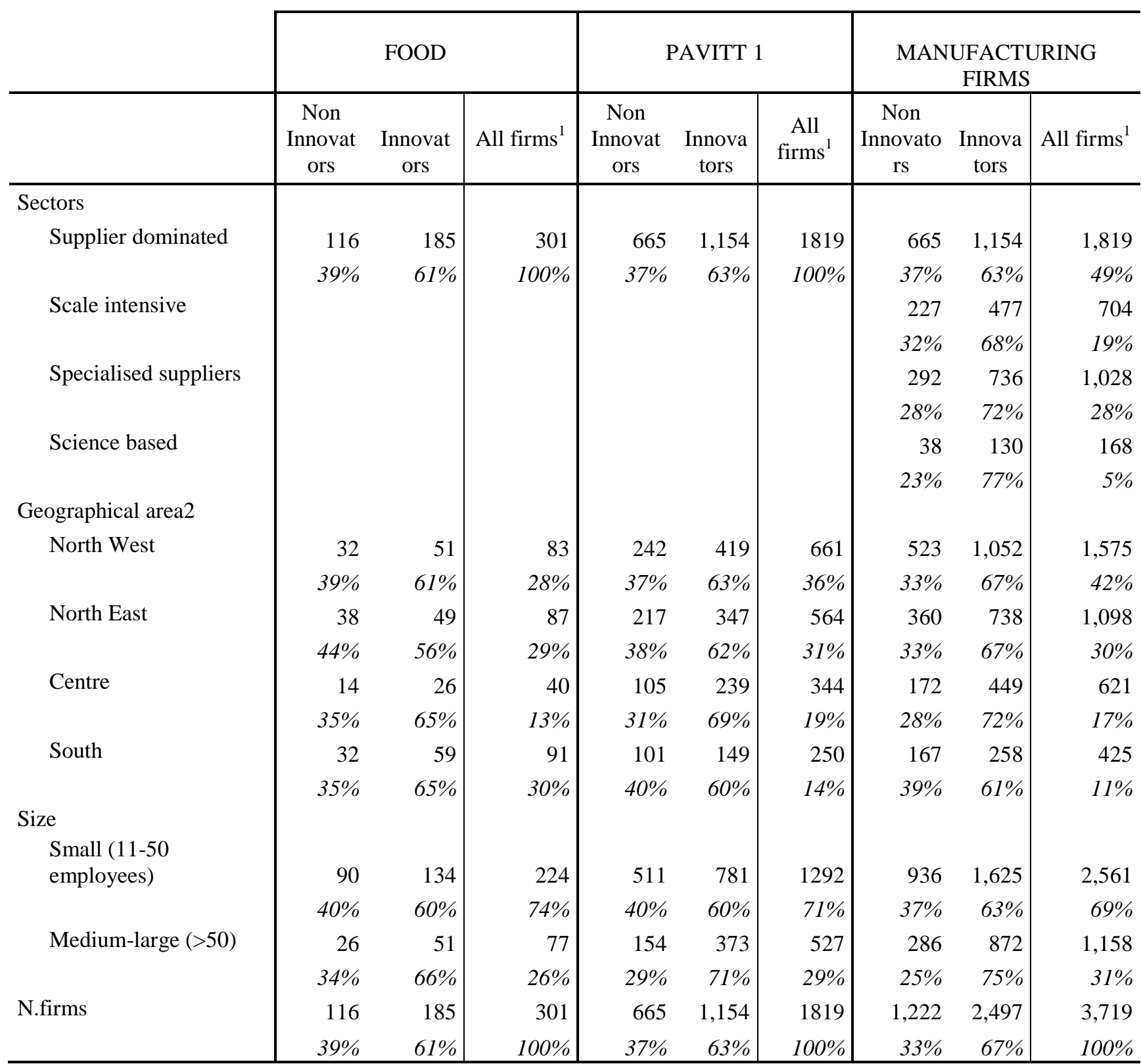

1 Shares of firms with respect to the total of the specified group.

2 North West: Liguria, Lombardia, Piemonte and Valle d'Aosta; North East: Emilia-Romagna, Trentino Alto-Adige, Friuli Venezia-Giulia and Veneto; Centre: Marche, Lazio, Toscana, and Umbria; South: Abruzzo, Basilicata, Calabria, Campania, Molise, Puglia, Sardegna and Sicilia.

Source: authors' elaborations on data from UniCredit-Capitalia (2008)

\subsection{Econometric specification}

The aim of the empirical analysis is to investigate the effect of university TT activities on a firm's likelihood to innovate. More precisely, we focus on the effect on a firm's innovation propensity of the TT activities of universities located in the province where the firm operates. The decision to use the province (NUTS 3 level) as the territorial unit for university variables is motivated by the 
relevance of geographic proximity for tacit knowledge (Jaffe, 1989; Audretsch and Feldman, 1996; Anselin et al, 1997). ${ }^{6}$

Our dependent variable Inno is a 0/1 variable that takes a value of 1 when a firm reports introducing at least one innovation (product, process or organisational innovation) during the 2004-2006 period. Given the nature of our dependent variable, we adopt a probit model and introduce into the model a set of explanatory variables which, in accordance with the relevant literature, may influence the probability to innovate.

In particular, we estimate the following model

$$
\begin{aligned}
& P\left(\text { Inno }_{i j}=1 / x_{i j}\right)=\Phi\left(\beta_{0}+\beta_{1} \ln E M P_{i j}+\beta_{2} \ln K_{i j}+\beta_{3} R D_{i j}+\beta_{4} \ln C L_{i j}+\beta_{5} \text { Age }_{i j}+\right. \\
& \left.\beta_{6} \text { North }_{i j}+\beta_{7} \text { Pav }_{i j}+\beta_{8} \text { Pav }_{i j}+\beta_{9} \text { Pav }_{i j}+\beta_{10} A g g l_{j}+\beta_{11} \text { Patents }_{j}+\beta_{12} \text { Uni_TT }_{j}\right)
\end{aligned}
$$

where $i=1, \ldots, N$ indicates firms and $j=1,2, \ldots, P$ stands for provinces. As regards firm specific characteristics, we include firm size as indicated by its number of employees in 2005 (EMP), stock of physical capital at firm level $(K)$, proxied by 2005 tangible fixed assets, R\&D intensity (average 2004-2006 R\&D expenditures as a share of sales) of firms (RD), a proxy of labour quality $(C L)$ represented by the 2005 cost of labour per employee and, finally, a proxy of firm experience given by the number of years the firm has operated (Age). We introduce a dummy variable (North) equal to one if a firm is located in the North of Italy and zero otherwise. Moreover, we introduce a set of sector dummies when we consider the sample of manufacturing firms, grouping firms according to the Pavitt taxonomy (the control group is the supplier-dominated group, Pav2 refers to the scale-intensive category, Pav3 to specialised suppliers and Pav4 is the science-based group). We control for the impact of agglomeration at provincial level by both considering a general measure ( $\mathrm{Aggl}$ ) as the province's industry density (number of firms per 100 inhabitants) in 2004 and a more specific measure as the patent intensity indicator (Patents), calculated on the basis of the total number of national patents registered at the European Patent Office (EPO) per 1000 inhabitants in 2003 (source: ISTAT http://www.istat.it/it/archivio/16777). The variable of interest, Uni_TT identifies the indicator of research upgrading and Transfer Technology activities, i.e. patenting, spin-offs and number of partnerships. In its construction, we refer to the methodology, data and weights that the Italian National Committee for Research Evaluation (CIVR) uses to calculate this indicator, but we aggregate the data on a provincial basis (see Appendix for details). ${ }^{7}$

\footnotetext{
${ }^{6}$ Provinces are one of the three different levels of local government (regions, provinces and municipalities) in Italy. According to the basic principles of the Nomenclature of Territorial Units for Statistics (NUTS) established by Eurostat and used by the European Commission, Italian provinces are NUTS 3 level.

${ }^{7}$ Italian universities (76) are located in 49 out of the 107 Italian provinces. In particular, 37 provinces have just one university, 8 provinces have 2 universities and 1 province (Pisa) has 3 universities; a marked concentration of universities exists in the provinces of Naples (5 universities), Milan (7) and Rome (8). For the multi-campus universities with an organised central campus and several peripheral ones, we consider that the data refers to the province in which
} 
The indicator is then added to each company in our dataset on the base of its territorial location. Nominal values have been deflated. ${ }^{89}$

Firm size is, in general, a very important factor in companies' innovation behaviour (see Schumpeter 1942). However, there is no strong a priori expectation about the sign of the size variable since there are arguments which support the idea of an innovative superiority in large firms and others suggesting an innovative superiority of small firms (Acs and Audretsch, 1987). Indeed, large firms may benefit from better access to human, financial resources and profit persistence (Hirsch et al 2013), while SMEs may have advantages from flexibility and interpersonal communication. Capital at firm level allows consideration of innovative strategies based on the acquisition of innovation which is embodied in capital goods developed by external suppliers. Investments in $R \& D$ and the quality of the labour force provide a firm with the capability not only to develop new products and processes, but also to absorb knowledge developed outside the firm (Cohen and Levinthal, 1990). Therefore, we expect the level of R\&D intensity and human capital to influence the likelihood to innovate positively. Age is introduced as a measure of firm experience in line with studies showing a link between firm age and innovation (Balasubramanian and Lee, 2008; Huergo and Jaumandreu, 2004). ${ }^{10}$ In addition, the model controls for sectoral and territorial effects. Territorial aspects are particularly relevant in the Italian context since the country exhibits pronounced geographical disparities: Northern regions tend to have a higher level of income and private R\&D investment and a more developed industrial structure (for more details see Iuzzolino et al, 2011, and Istat, 2008).

Finally, since there are many indications from the empirical literature that innovative activities tend to benefit from agglomeration (see Feldman, 1999, and Doring and Schnellenbach, 2006, for a survey), we control for the impact of agglomeration considering a general indicator, the province's

the central location of the multi-campus university is found, since only teaching activity is performed locally in most cases, whereas research is based at the central location (one exception is "Università Cattolica del Sacro Cuore").

${ }^{8}$ For the tangible fixed assets, values have been deflated by using the average production price indices of the following sectors: machines and mechanical appliances, electrical machines and electrical equipment, electronics and optics and means of transport. The source of the sectoral indices is ISTAT. As regards the cost of labour, data have been deflated by using the consumer price index for families of workers and office workers provided by ISTAT.

${ }^{9}$ In the appendix, a brief description of variables used in the empirical analysis (table A1), descriptive statistics (table A2) and correlation matrix for observation in the manufacturing sector (table A3) are reported. We have also computed variance inflation factors for independent variables of eq. [1] and they are no significantly higher than 2, so suggesting that there is no multicollinearity among the explanatory variables.

${ }^{10}$ Balasubramanian and Lee (2008) examine how firm age relates to a specific aspect of innovation, technical quality, as measured by the number of citations of a patent, and find that it decreases with firm age. By looking at the probability manufacturing firms at different stages of their lives have of introducing innovations, Huergo and Jaumandreu (2004) show that firms in the youngest cohorts in Spain tend to innovate more while the oldest ones tend to innovate less than entrants. However, some firms above an intermediate age (20 to 36 years) appear to be almost as active as entering firms, especially in product innovations. 
industry density, and the patent intensity indicator, a proxy which relates more to knowledge-based interactions. ${ }^{11}$

As regards the estimation method, the assumption that errors are independent might be violated since firms from the same province are likely to be more similar than firms from different provinces (because of socio-economic factors, for example). For this reason, we control for a potential downward bias in the estimated errors by clustering firms at provincial level.

\section{ECONOMETRIC RESULTS}

Equation [1] has been estimated by considering three samples: the sub-sample of food firms, the sub-sample of firms belonging to the supplier-dominated group and, finally, all the sample of manufacturing firms. The comparison of the three samples of firms allows us to get some indications of the determinants of innovation performance in the food sector with particular attention given to the role of university technological transfer and to the differences between this industry, the Pavitt sector to which food belongs and the manufacturing sector as a whole.

For Pavitt's (1984) taxonomy, the food industry is classified as "supplier dominated" (Pavitt 1) since the origins of technological change in this sector seem to lie chiefly with supplier industries, i.e. machinery and equipment manufacturers. However, Rama (1996) points out how processors of high value-added foodstuffs rely more on food inventions than on innovation in machinery, chemicals, etc. Moreover, Christensen et al. (1996) argue that the traditional perception of the industry does not render full justice to the innovativeness of food firms in general. They claim that the food industry actively combines a wide range of different new techniques and scientific discoveries and plays a significant role in selecting and adapting them. For these reasons we expect some differences when comparing food firms and firms belonging to the supplier dominated group. The results of the regressions are reported in Table 2. Column (1) reports the estimated results for food, column (2) gives the results for Pavitt 1 and column (3) presents those for the manufacturing sector.

Of firm level variables, only physical capital and R\&D intensity show significant coefficients for the food industry. The positive effect of physical capital could be due to the fact that carrying out innovation requires the use of machinery and fixed equipment. Firm R\&D investment also enhance the likelihood of introducing an innovation. This last result is in line with the work on the same sector by Maietta (2014) and Capitanio et al (2010) for Italy and Triguero et al (2011) for Spain, as

\footnotetext{
${ }^{11}$ Jaffe et al (1993) have shown that spillovers are geographically localised by comparing the geographical location of patent citations with that of the cited patents. Indeed, for the USA, they found that citations of domestic patents are more likely to be domestic, and more likely to come from the same state and metropolitan area.
} 
well as with previous studies of manufacturing industry (see, among others, Conte, 2009 for Italy and Smit et al, 2013 for the Netherlands).

In line with Maietta (2015), Alfranca et al (2003) and Barterle et al (2011), the size variable of the food firms does not support the Schumpeterian hypothesis. In particular, the dummies for size class are not significant in Maietta (2015), except for small-sized Italian firms. In Alfranca et al. (2003), there is no systematic relationship between firm size and innovation intensity in the case of American food multinationals. Finally, in Barterle et al (2011), the relationship between innovativeness and firm size is significant, but negative for a sample of European SMEs, so underlining the fact that small businesses can innovate more than large companies and better adjust their business to market evolution and consumer preferences. In contrast, Huiban and Bouhsina (1998) show that the innovation propensity of French food firms is mainly determined by their size.

Firm experience and quality of human capital are not significant in the food industry: accumulated learning and the quality of labour do not seem to increase the probability to innovate. Similar results are obtained by Triguero et al (2013) for Spain. On the other hand, our results differ from the previous ones of Capitanio et al (2010) and Huiban and Bouhsina (1998). Capitanio et al (2010) found that the quality of human capital positively affects product innovators in the Italian food industry while firm age negatively affects this variable. Huiban and Bouhsina (1998) point out the importance of labour factor quality for food firms' innovation propensity in France.

The impact of firm characteristics differs slightly when the group of supplier dominated firms or the manufacturing sample is considered. For Pavitt 1, we find that all the firm level variables are significant (and positive), except for R\&D. It seems that firms in the supplier dominated sector benefit from labour force quality, but not from R\&D. Moreover, larger and older firms show a better performance. ${ }^{12}$

For manufacturing industry as a whole, firm size is in line with the Schumpeterian assumption, ${ }^{13}$ but age of firm, employee quality and firm R\&D investment also enhance the likelihood of introducing an innovation. ${ }^{14}$

\footnotetext{
${ }^{12}$ The results are broadly the same if the food industry is excluded from the Pavitt 1 group,.

${ }^{13}$ For Italy, the hypothesis of the innovative advantage of larger firms is confirmed by Conte (2009), but only for product innovation and not for process innovation, where small firms appear particularly active. For the Netherlands, Smit et al (2013) find a combination of a negative sign for goods innovations with a positive sign for process innovations.

${ }^{14}$ We have also considered two firm characteristics relating to ownership. First, we have tested whether the firm belongs to a group. Indeed, firms that form a unit in a larger entity may have access to more resources that affect their ability to innovate (Beugelsdijk, 2007). We find that the impact is not relevant. Furthermore, we have taken account of the possibility that the probability to innovate differs between family-owned firms and non-family firms (for a recent review, see De Massis et al 2013). We do not find support for such a hypothesis. However, this finding may be affected by the limitations of our data set which excludes firms with fewer than 10 workers (results available upon request).
} 
When we control for territorial effect, the dummy for North shows a negative coefficient weakly significant in the case of food when patents and spin-offs are considered as indicators of the university TT activities. Maietta (2015) finds also a negative and weakly significant coefficient of the dummy for North in the case of product innovation, while the variable is not significant for process innovation. The set of sector dummies in the manufacturing specification show positive and significant coefficients which indicate that the other Pavitt categories have a higher probability to innovate than the supplier-dominated sector (the control group).

With respect to the agglomeration variables in table 2 , it is worth noting that industry density has a positive and significant effect, which confirms that agglomeration economies drive innovation (Feldman, 1999), while the coefficient for patent intensity is not significant and these results apply to all the samples. One might suspect from these results that the innovative performance of Italian firms is affected by the general advantages of a high density of economic activities and not by the agglomeration of knowledge resources. The impact of agglomeration is more important for food, almost double that found for the manufacturing sector.

As regards the aim of our paper, we confirm that university technology transfer activities increase the likelihood of manufacturing firms' innovating and provide evidence that a similar even stronger positive effect exists for food enterprises.

Indeed, in table 2, the TT indicator shows a positive and significant effect on the innovative output of firms in the province where a given university is located and this impact appears to be significantly higher for the food industry (column 1) than for the manufacturing sector as a whole (column 3).

The general indicator of university TT is not significant for the supplier dominated sector. In line with the Pavitt taxonomy of innovating firms (Pavitt, 1984), these firms seem to rely more on innovative strategies based on the acquisition of innovation which is embodied in capital goods developed by external suppliers, as the positive and significant coefficient of capital intensity shows.

Our results indicate that the food industry is currently more active than the 'supplier-dominated' view implies since it is actually at the forefront in the application of a wide range of different scientific advances (Alfranca et al, 2006; Christensen et al, 1996). This result seems to confirm the idea that food firms benefit more from spillovers from universities than firms in the supplier dominated sector. ${ }^{15}$

\footnotetext{
${ }^{15}$ In Spain, on the other hand, the purchase of equipment, rather than information gathering procedures, emerged as the main source of technology acquisition for food firms, (Garcia Martinez \& Burns, 1999).
} 
The results for food and manufacturing are also in line with the findings of the two main strands of literature investigating the effect of university activities on the innovative performance of manufacturing firms. The first strand has mainly looked at the direct effect by using $R \& D$ cooperation as a measure of TT activities and the second strand has examined the spillover effect of university research (cfr. § 2). For Italy, the spillover effect is analysed by Piergiovanni et al (1997), Leten et al (2011) and Cardamone et al (2015). ${ }^{16}$

The results obtained by Maietta (2015), specifically for Italian food firms, are similar to ours. She shows that universities can be important for the innovative performance of food firms both through university-firm R\&D collaboration and through knowledge spillovers from local universities. Indeed, a firm within a radius of $150 \mathrm{~km}$ of a university has a higher likelihood of product innovation than a more distant firm does. However, the impact of codified knowledge production (the numbers of ISI-Scopus articles and citations) on local firms' product innovation is negative.

To better analyse the ways in which TT influence firm innovation performance, we consider (model 4-9) the number of university patents active up to the end of 2003 (Uni_Patents) and the number of spin-offs activated over the 2001-2003 period (Spin-off) (Source: MIUR, 2007). Moreover, we also take into account the effects of academic research performance by using a proxy for the quality of university research (models 10-13) to verify whether being located close to a top-tier university promotes innovation. Research performance indicator (Uni_Quality) is a composite indicator for the various universities based on the evaluation of research output carried out over the 2001-2003 period by CIVR-VTR (MIUR, 2007). ${ }^{17}$

The firm-level effects in regressions 4-13 show similar results for coefficient signs and significance, confirming the evidence obtained by considering the TT indicator: university patents and spin-off firms positively affect the probability firms that operate in the food and manufacturing sector have of innovating. What is more, the effect of the quality indicator is positive and significant for the food industry, that is in line with manufacturing firms but not with the supplier dominated sector. It seems that the higher the quality of universities located in the province is, the more

\footnotetext{
${ }^{16}$ Piergiovanni et al (1997) use patented innovations at the regional level over the 1978-86 period and product innovations at the provincial level for the year 1989 and show that local spillovers from academic research are an important source of innovation in small firms. Leten et al (2011) estimate regional knowledge production functions for 101 Italian provinces over the 1995-2001 period and found a strong positive relationship between industrial technological performance and the presence of nearby universities. Cardamone et al (2015) show that TT activities play a significant role in the probability of innovation by Italian manufacturing firms located in the same province as the university, especially in some territorial areas (North-East and Center), sectors (science based and scale intensive) and among specific firms (large firms).

${ }^{17}$ For the various structures (universities and research centres), a composite index, suitable for the allocation of state funds, was produced. This index relates to product quality, property rights on the products, international mobility propensity, advanced training propensity, ability to attract financial resources and ability in using available funds to finance research. For more information, see the website: http://vtr2006.cineca.it/index_EN.html.
} 
widespread the effect on firms' innovative performance is, as is highlighted in the seminal articles by Mansfield (1991, 1995). This result is consistent with that of Laursen et al (2011), who, from analysing university-industry collaboration in the United Kingdom, report that firms' decisions to collaborate with universities for innovation are influenced by both the geographical proximity and quality of these universities.

\section{INVESTIGATING THE EFFECT OF EXTERNALITIES OF TT ACTIVITIES}

We assumed in the previous sections that TT spillovers are spatially localised, in the sense that they occur for firms in the same province as a given university. However, it is likely that these externalities are not limited to the provincial level, but may occur over greater distances as well. For the USA, Anselin et al (1997) found a significant effect of both university research in a given metropolitan statistical area (MSA), and its surrounding counties, on innovative activities in that MSA.

Since knowledge spillovers from academic research are likely to result from mechanisms such as spin-off dynamics and labour mobility, the occurrence of such spillovers could be assumed to diminish with geographical distance (Ponds et al, 2010). Indeed, a number of papers point out the nexus between spatial agglomeration and knowledge spillovers (Aldieri and Cincera, 2009; Arrow,1962; Audretsch and Feldman, 2004; Bottazzi and Peri, 2003; Koo, 2005). Hence, we verify whether TT from other provinces might also affect the innovative performance of Italian manufacturing firms. In so doing, we take into account distances between provinces in which universities and firms are located. In other words, we examine whether TT activities undertaken by universities in provinces other than that in which the firm is located might affect its innovativeness, that is whether knowledge generated by public research in other provinces leads to externalities which produce innovation (Autant-Bernard, 2001).

In more detail, our specification becomes:

$$
\begin{gathered}
P\left(\text { Inno }_{i j}=1 / \mathbf{x}_{i j}\right)=\Phi\left(\beta_{0}+\beta_{1} \ln E M P_{i j}+\beta_{2} \ln K_{i j}+\beta_{3} R D_{i j}+\beta_{4} \ln C L_{i j}+\beta_{5} A_{g e}+\beta_{6} \text { North }_{i j}+\right. \\
\left.\beta_{7} \text { Pav }_{i j}+\beta_{8} \text { Pav }_{i j}+\beta_{9} \text { Pav }_{i j}+\beta_{10} \text { Aggl }_{j}+\beta_{11} \text { Patents }_{j}+\beta_{12} \text { Uni }_{-} T T_{j}+\beta_{13} \text { Uni_TTOther }_{j}\right)
\end{gathered}
$$

where Uni_TTOther $r_{j}$ indicates the TT of universities in other provinces. It is determined as the weighted sum of the TT indicators of other provinces, that is:

Uni_TTOther ${ }_{j}=\sum_{i \neq j} \omega_{i j} U n i \_T T_{i}$ 
in which $\omega_{i j}$, is the generic element of the spatial weighting matrix $W$, computed by considering the distance between provinces $i$ and $j .{ }^{18}$ As TT indicators, we have considered the overall TT index as well as the other university indicators, i.e. patents, spinoffs and university quality. Results are reported in table 3. Our results show that TT activities undertaken by universities in other provinces do not affect innovative performance of Italian manufacturing firms. This result is robust whatever the group of firms considered, that is food industry, traditional sector or manufacturing firms. The only exception regards the estimation made using the CIVR indicator and only for the manufacturing firm estimation, the results of which suggest that firm innovative output is also affected by the quality of universities located in other provinces. This finding is in line with the evidence about university-firm collaboration for UK. When deciding to collaborate with universities, firms appear to give preference to university research quality over geographical closeness: in the absence of a nearby high-quality university, the second-best choice is collaboration with a non-local university (Laursen et al, 2011).

The results on our variable of interest do not substantially vary with respect to those obtained when TT externalities from other provinces are not considered, even though we now also find a significant effect of patents and spinoffs on innovative output for firms in the traditional sector, with an effect which is higher than that for manufacturing firms, but lower than that for firms in the food sector. However, this result is driven by food firms in the traditional sector: if we exclude these from Pavitt 1 firms, the effect of the TT indicator becomes not significant, as was found in the previous section. ${ }^{19}$

To sum up, our results confirm the important role of local spatial externalities (Anselin et al, 1997, Autant-Bernard, 2001) and show that only knowledge spillovers from local TT activities affect the probability that a firm will innovate. In a nutshell, we find that distance matters. This could be due to the fact that geographic proximities encourage face-to-face contacts, which are an important vector of knowledge flows, especially if knowledge has an important tacit component (AutantBernard, 2012).

\footnotetext{
${ }^{18}$ The weighting matrix $\mathrm{W}$ is computed by using the spmat command of Drukker et al (2013) and considering min-max normalized inverse distance matrix. Distances are computed by using the latitude and longitude coordinates of each province (source: World Gazetteer) and considering the haversine formula.

${ }^{19}$ Results are available upon request.
} 
Table 2. Estimation results on the probability to introduce an innovation

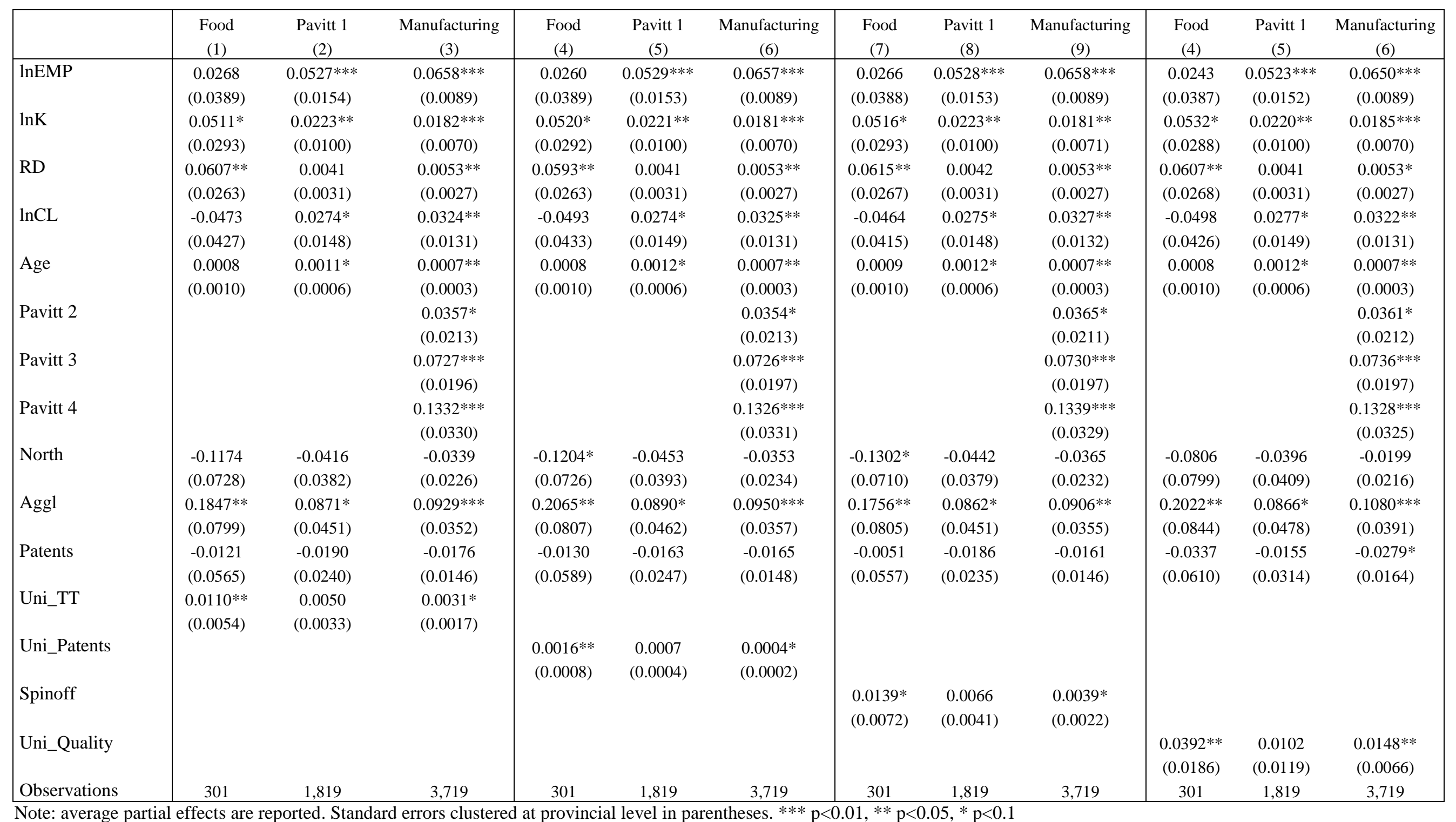


Table 3. Estimation results with the inclusion of the indicator of TT activities in other provinces

\begin{tabular}{|c|c|c|c|c|c|c|c|c|c|c|c|c|}
\hline & FOOD & Pavitt 1 & Manufacturing & FOOD & Pavitt 1 & Manufacturing & FOOD & Pavitt 1 & Manufacturing & $\mathrm{F} \& \mathrm{~B}$ & Pavitt 1 & Manufacturing \\
\hline $\operatorname{lnEMP}$ & $\begin{array}{c}0.0268 \\
(0.0388)\end{array}$ & $\begin{array}{c}0.0527 * * * \\
(0.0155)\end{array}$ & $\begin{array}{c}0.0658 * * * \\
(0.0089)\end{array}$ & $\begin{array}{c}0.0264 \\
(0.0389)\end{array}$ & $\begin{array}{c}0.0527 * * * * \\
(0.0155)\end{array}$ & $\begin{array}{c}0.0656 * * * \\
(0.0089)\end{array}$ & $\begin{array}{c}0.0266 \\
(0.0387)\end{array}$ & $\begin{array}{c}0.0528 * * * \\
(0.0154)\end{array}$ & $\begin{array}{c}0.0660 * * * * \\
(0.0089)\end{array}$ & $\begin{array}{c}0.0242 \\
(0.0386)\end{array}$ & $\begin{array}{c}0.0525 * * * \\
(0.0153)\end{array}$ & $\begin{array}{c}0.0648^{* * *} \\
(0.0089)\end{array}$ \\
\hline $\ln \mathrm{K}$ & $\begin{array}{l}0.0509^{*} \\
(0.0293)\end{array}$ & $\begin{array}{c}0.0231 * * \\
(0.0103)\end{array}$ & $\begin{array}{c}0.0184 * * * \\
(0.0070)\end{array}$ & $\begin{array}{l}0.0515^{*} \\
(0.0290)\end{array}$ & $\begin{array}{c}0.0231 * * \\
(0.0102)\end{array}$ & $\begin{array}{c}0.0183 * * * \\
(0.0070)\end{array}$ & $\begin{array}{c}0.0516^{*} \\
(0.0293)\end{array}$ & $\begin{array}{c}0.0230 * * \\
(0.0103)\end{array}$ & $0.0184 * * *$ & $0.0535^{*}$ & $0.0224 * *$ & $0.0191 * * *$ \\
\hline $\mathrm{RD}$ & $\begin{array}{c}0.0610^{* *} \\
(0.0265)\end{array}$ & $\begin{array}{c}0.0041 \\
(0.0031)\end{array}$ & $\begin{array}{c}0.0053 * * \\
(0.0027)\end{array}$ & $\begin{array}{c}0.0596 * * \\
(0.0264)\end{array}$ & $\begin{array}{c}0.0041 \\
(0.0031)\end{array}$ & $\begin{array}{c}0.0053 * * \\
(0.0027)\end{array}$ & $\begin{array}{c}0.0615 * * \\
(0.0267)\end{array}$ & $\begin{array}{c}0.0042 \\
(0.0032)\end{array}$ & $\begin{array}{c}0.0053 * * \\
(0.0027)\end{array}$ & $\begin{array}{l}0.0601 * * \\
(0.0265)\end{array}$ & $\begin{array}{c}0.0041 \\
(0.0031)\end{array}$ & $\begin{array}{l}0.0052^{*} \\
(0.0027)\end{array}$ \\
\hline $\operatorname{lnCL}$ & $\begin{array}{l}-0.0467 \\
(0.0427)\end{array}$ & $\begin{array}{l}0.0260 * \\
(0.0148)\end{array}$ & $\begin{array}{c}0.0319 * * \\
(0.0131)\end{array}$ & $\begin{array}{l}-0.0483 \\
(0.0432)\end{array}$ & $\begin{array}{l}0.0257^{*} \\
(0.0148)\end{array}$ & $\begin{array}{c}0.0321 * * \\
(0.0130)\end{array}$ & $\begin{array}{l}-0.0464 \\
(0.0416)\end{array}$ & $\begin{array}{l}0.0262 * \\
(0.0148)\end{array}$ & $\begin{array}{c}0.0320 * * \\
(0.0132)\end{array}$ & $\begin{array}{l}-0.0510 \\
(0.0420)\end{array}$ & $\begin{array}{l}0.0268^{*} \\
(0.0150)\end{array}$ & $\begin{array}{c}0.0312 * * \\
(0.0131)\end{array}$ \\
\hline Age & $\begin{array}{c}0.0008 \\
(0.0010)\end{array}$ & $\begin{array}{l}0.0011^{*} \\
(0.0006)\end{array}$ & $\begin{array}{c}0.0007 * * \\
(0.0003)\end{array}$ & $\begin{array}{c}0.0008 \\
(0.0010)\end{array}$ & $\begin{array}{l}0.0011^{*} \\
(0.0006)\end{array}$ & $\begin{array}{c}0.0007 * * \\
(0.0003)\end{array}$ & $\begin{array}{c}0.0009 \\
(0.0010)\end{array}$ & $\begin{array}{l}0.0011^{*} \\
(0.0006)\end{array}$ & $\begin{array}{c}0.0007 * * \\
(0.0003)\end{array}$ & $\begin{array}{c}0.0008 \\
(0.0010)\end{array}$ & $\begin{array}{l}0.0012^{*} \\
(0.0006)\end{array}$ & $\begin{array}{c}0.0007 * * \\
(0.0003)\end{array}$ \\
\hline Aggl & $\begin{array}{c}0.1995^{* *} \\
(0.0921)\end{array}$ & $\begin{array}{c}0.0658 \\
(0.0535)\end{array}$ & $\begin{array}{c}0.0788 * * \\
(0.0381)\end{array}$ & $\begin{array}{c}0.2198 * * \\
(0.0944)\end{array}$ & $\begin{array}{c}0.0668 \\
(0.0514)\end{array}$ & $\begin{array}{c}0.0814 * * \\
(0.0398)\end{array}$ & $\begin{array}{l}0.1769 * \\
(0.0969)\end{array}$ & $\begin{array}{c}0.0671 \\
(0.0514)\end{array}$ & $\begin{array}{l}0.0721 * \\
(0.0384)\end{array}$ & $\begin{array}{c}0.1851 \\
(0.1129)\end{array}$ & $\begin{array}{c}0.0727 \\
(0.0588)\end{array}$ & $\begin{array}{l}0.0736 * \\
(0.0431)\end{array}$ \\
\hline Patents & $\begin{array}{l}-0.0068 \\
(0.0572)\end{array}$ & $\begin{array}{l}-0.0249 \\
(0.0223)\end{array}$ & $\begin{array}{l}-0.0214 \\
(0.0147)\end{array}$ & $\begin{array}{l}-0.0092 \\
(0.0583)\end{array}$ & $\begin{array}{l}-0.0222 \\
(0.0225)\end{array}$ & $\begin{array}{c}-0.0194 \\
(0.0142)\end{array}$ & $\begin{array}{l}-0.0046 \\
(0.0585)\end{array}$ & $\begin{array}{l}-0.0262 \\
(0.0229)\end{array}$ & $\begin{array}{c}-0.0229 \\
(0.0147)\end{array}$ & $\begin{array}{l}-0.0425 \\
(0.0669)\end{array}$ & $\begin{array}{c}-0.0211 \\
(0.0298)\end{array}$ & $\begin{array}{c}-0.0418 * * \\
(0.0163)\end{array}$ \\
\hline Pavitt 2 & & & $\begin{array}{c}0.0350 \\
(0.0214)\end{array}$ & & & $\begin{array}{c}0.0345 \\
(0.0214)\end{array}$ & & & $\begin{array}{l}0.0354^{*} \\
(0.0213)\end{array}$ & & & $\begin{array}{c}0.0342 \\
(0.0214)\end{array}$ \\
\hline Pavitt 3 & & & $\begin{array}{c}0.0720 * * * \\
(0.0195)\end{array}$ & & & $\begin{array}{c}0.0721 * * * \\
(0.0195)\end{array}$ & & & $\begin{array}{c}0.0720 * * * \\
(0.0195)\end{array}$ & & & $\begin{array}{c}0.0724 * * * \\
(0.0197)\end{array}$ \\
\hline Pavitt 4 & & & $\begin{array}{c}0.1331 * * * \\
(0.0329)\end{array}$ & & & $\begin{array}{c}0.1322 * * * \\
(0.0329)\end{array}$ & & & $\begin{array}{c}0.1338 * * * \\
(0.0328)\end{array}$ & & & $\begin{array}{c}0.1323 * * * * \\
(0.0324)\end{array}$ \\
\hline North & $\begin{array}{l}-0.1069 \\
(0.0707)\end{array}$ & $\begin{array}{c}-0.0528 \\
(0.0417)\end{array}$ & $\begin{array}{l}-0.0409 * \\
(0.0227)\end{array}$ & $\begin{array}{l}-0.1090 \\
(0.0778)\end{array}$ & $\begin{array}{c}-0.0666 \\
(0.0447)\end{array}$ & $\begin{array}{c}-0.0469 * \\
(0.0251)\end{array}$ & $\begin{array}{c}-0.1293^{* *} \\
(0.0641)\end{array}$ & $\begin{array}{l}-0.0567 \\
(0.0421)\end{array}$ & $\begin{array}{c}-0.0477 * * \\
(0.0232)\end{array}$ & $\begin{array}{l}-0.0811 \\
(0.0801)\end{array}$ & $\begin{array}{l}-0.0390 \\
(0.0402)\end{array}$ & $\begin{array}{l}-0.0176 \\
(0.0213)\end{array}$ \\
\hline $\begin{array}{l}\text { Uni_TT } \\
\text { Uni_TTOther }\end{array}$ & $\begin{array}{l}0.0103 * \\
(0.0057) \\
-0.0399 \\
(0.1002)\end{array}$ & $\begin{array}{c}0.0060 \\
(0.0037) \\
0.0544 \\
(0.0674)\end{array}$ & $\begin{array}{c}0.0039 * * \\
(0.0019) \\
0.0356 \\
(0.0355)\end{array}$ & & & & & & & & & \\
\hline $\begin{array}{l}\text { Uni_Patents } \\
\text { Uni_PatentsOther }\end{array}$ & & & & $\begin{array}{l}0.0014 * \\
(0.0008) \\
-0.0065 \\
(0.0180)\end{array}$ & $\begin{array}{c}0.0010^{*} \\
(0.0005) \\
0.0125 \\
(0.0108)\end{array}$ & $\begin{array}{c}0.0006 * * \\
(0.0003) \\
0.0070 \\
(0.0068)\end{array}$ & & & & & & \\
\hline Spinoff & & & & & & & $\begin{array}{l}0.0138^{*} \\
(0.0079)\end{array}$ & $\begin{array}{l}0.0083^{*} \\
(0.0050)\end{array}$ & $\begin{array}{c}0.0056^{* *} \\
(0.0025)\end{array}$ & & & \\
\hline Uni_SpinoffOther & & & & & & & $\begin{array}{l}-0.0037 \\
(0.1306)\end{array}$ & $\begin{array}{c}0.0651 \\
(0.0858)\end{array}$ & $\begin{array}{c}0.0599 \\
(0.0458)\end{array}$ & & & \\
\hline Uni_Quality & & & & & & & & & & $\begin{array}{c}0.0421 * * \\
(0.0194)\end{array}$ & $\begin{array}{c}0.0125 \\
(0.0118)\end{array}$ & $\begin{array}{c}0.0208 * * * \\
(0.0065)\end{array}$ \\
\hline Uni_QualityOther & & & & & & & & & & $\begin{array}{c}0.0993 \\
(0.3544)\end{array}$ & $\begin{array}{c}0.0797 \\
(0.1647)\end{array}$ & $\begin{array}{c}0.2002 * * \\
(0.0883)\end{array}$ \\
\hline Observations & 301 & 1,819 & 3,719 & 301 & 1,819 & 3,719 & 301 & 1,819 & 3,719 & 301 & 1,819 & 3,719 \\
\hline
\end{tabular}

Note: average partial effects are reported. Standard errors clustered at provincial level in parentheses. $* * * \mathrm{p}<0.01, * * \mathrm{p}<0.05, * \mathrm{p}<0.1$ 


\section{CONCLUSIONS}

The relationship between university and industry is receiving increasing attention in both theoretical and empirical literature. Many works on this subject have been carried out over recent years. Previous research mainly focused on the high-tech sectors or manufacturing as a whole, paying little attention to the role of university-industry cooperation for the food industry.

In this paper, we focus on the context of the university-industry relationship in the food sector and explore the specificities of this relationship in Italy in order to get a better understanding of whether universities can support innovation in these industries and whether distance matters for spillovers from university technology transfer activities.

Results show that university TT activities seem to augment the probability nearby food firms have of innovating, while they do not seem to play a significant role for firms in the supplier dominated sector. More relevant, the impact of such activities on firm innovation appears significantly higher in the food industry than in the manufacturing sector as a whole.

Therefore, we provide further evidence that the perception of the food industry as a traditional sector does not render full justice to the innovativeness of food firms in general (Christensen et al, 1996). Food companies appear innovative in a specific way and the universities located near firms seem to be a central element of this specificity.

Moreover, our results also indicate that TT activities undertaken by universities in other provinces do not affect the innovative performance of Italian manufacturing firms, so confirming the important role of local spatial externalities (Anselin et al, 1997, Autant-Bernard, 2001). According to this view, only knowledge spillovers from local TT activities affect firms' probability of innovating.

Our study may have potentially interesting implications. The design and implementation of appropriate technology transfer policies require deeper comprehension of the context and characteristics of the existing university-industry collaboration in different economic sectors. By identifying the factors driving a firm's innovation performance in the food sector, this study provides two insights which may help promote innovation in the food sector.

First, the factors that influence innovative capability in the food sector are different from those in other sectors, suggesting the need for sector specific instruments for promoting innovation. For example, when considering firms' internal factors, the propensity to innovate depends on $R \& D$, but not on company age in the food sector. Thus, accumulated learning does not seem to increase the probability to innovate in the food sector, while the opposite occurs in other traditional sectors.

Second, science is important in the food industry and this raises questions about the policy of mainly considering high-tech industries when promoting a closer relationship between firms and 
universities. Government should encourage knowledge transfers in the agrifood sector, where the high levels of scientific knowledge in fields such as biotechnology or chemicals are not yet completely exploited (Acosta et al, 2011). Such a policy could contribute to overcoming the European Paradox, i.e. the gap between the high scientific performance of European research and low utilisation of its results by industry.

It should be noted that this study has some limitations. First, it analyses the role of universityindustry collaboration from a firm point of view. It would be interesting to investigate the perspectives of university in order to better understand the motivations and barriers for collaborating with firms. Second, our analysis was carried out considering a single country. It would be interesting to look at the extent to which these results can be generalised to include other European countries given that cross country differences may exist between specific academic, industrial and political contexts. Finally, the analysis has provided a static picture of the relationships between firm innovation and university, where the latter has been found to affect the former in a short time span. 


\section{APPENDIX - INDICATOR ON RESEARCH UPGRADING AND TRANSFER ACTIVITIES}

The university technology transfer indicator used in this paper are built by Cardamone et al, 2015 . They use the results of the first National Triennial Research Evaluation exercise for the years 20012003 (VTR 2001-03, in MIUR, 2007). The Exercise was entrusted to the Italian National Committee for Research Evaluation (CIVR) to evaluate the scientific performance of universities (both State and private) and research institutions. In this evaluation process, the CIVR developed an indicator of upgrading research and transfer activities for each university that takes account of the patenting, spin-offs activated and the number of partnerships, and weighted these elements on the basis of their relevance.

The provincial level TT indicator is equal to zero if there is no university in the province, while for the $\mathrm{j}$-th province with $\mathrm{u}=1, \ldots, \mathrm{U}_{\mathrm{p}}$ universities, where $\mathrm{U}_{\mathrm{p}}$ varies from one to eight (see Figure $1)$, is computed as:

$T T_{-} U n i_{j}=\frac{1}{10}\left\{\frac{\sum_{u=1}^{U_{p}} \operatorname{PAT}_{u j}}{\sum_{u=1}^{76} \operatorname{PAT}_{u}}+\frac{\sum_{u=1}^{U_{p}} \operatorname{PATact}_{u j}}{\sum_{u=1}^{76} \text { PATact }_{u}}+2 \frac{\sum_{u=1}^{U_{p}} R E V_{u j}}{\sum_{u=1}^{76} R E V_{u}}+4 \frac{\sum_{u=1}^{U_{p}} \operatorname{SPIN}_{u j}}{\sum_{u=1}^{76} \operatorname{SPIN}_{u}}+2 \frac{\sum_{u=1}^{U_{p}} P A R T_{u j}}{\sum_{u=1}^{76} P A R T_{u}}\right\} \times 100$

where $P A T_{u}=P A T_{u}{ }^{N A T}+1,5 P A T_{u}{ }^{I N T}$, with $P A T_{u}{ }^{N A T}$ indicating the number of national patents of the u-th university registered during the 2001-2003 and $P A T_{u}{ }^{I N T}$ expressing the number of international patents of the u-th university during the 2001-2003 period. Similarly, PATact $t_{u}$ is based on the sum of national $\left(\right.$ PATact $\left._{u}{ }^{N A T}\right)$ and international $\left(\right.$ PATact $\left._{u}{ }^{I N T}\right)$ patents active on 31/12/2003 for the u-th university, that is PATact $_{u}=$ PATact $_{u}{ }^{N A T}+1,5$ PATact $_{u}{ }^{I N T}$. Moreover, $R E V_{u}$ is the revenues from patent selling and licensing during 2001-2003, $\operatorname{SPIN}_{u}$ indicates the number of spin-offs activated for 2001-2003 and $P A R T_{u}$ is the number of partnerships (with receipts of above 500,000 Euros for the Structure) active for 2001-2003 for the u-th university. 
Table A1. List and description of variables used in the empirical investigation

\begin{tabular}{|c|c|}
\hline VARIABLE & DESCRIPTION \\
\hline Inno & $\begin{array}{l}\text { dummy equal to one when a firm reports introducing at least one innovation (product, process or organizational innovation) } \\
\text { over the 2004-2006 period }\end{array}$ \\
\hline \multicolumn{2}{|l|}{ Firms variables } \\
\hline $\operatorname{lnEMP}$ & number of employees in 2005 \\
\hline $\ln \mathrm{K}$ & tangible fixed assets in 2005 \\
\hline $\mathrm{RD}$ & R\&D expenditures as a share of sales of firms (average 2004-2006) \\
\hline $\operatorname{lnCL}$ & cost of labour per employee in 2005 \\
\hline Age & number of years of the firm \\
\hline $\mathrm{Pav}$ & $\begin{array}{l}\text { Pav1 refers to supplier-dominated group, Pav2 to scale-intensive category, Pav3 to specialized suppliers and Pav4 to science- } \\
\text { based group }\end{array}$ \\
\hline North & dummy equal to one if a firm is located in the North of Italy \\
\hline \multicolumn{2}{|l|}{ Territorial variables } \\
\hline Aggl & number of firms per 100 inhabitants in 2004 (data at NUTS 3 level) \\
\hline Patents & number of national patents registered at the European Patent Office (EPO) per 1000 inhabitants in 2003 (data at NUTS 3 level) \\
\hline \multicolumn{2}{|l|}{ University indicators } \\
\hline Uni_TT & University indicator on research upgrading and transfer activities over the 2001-2003 period (see Appendix) \\
\hline Uni_Patents & number of patents that are active up to the end of 2003 \\
\hline Spin-off & number of spin-offs activated over the 2001-2003 period \\
\hline Uni_Quality & CIVR-VTR indicator over the 2001-2003 period (see note 19) \\
\hline
\end{tabular}


Table A2. Descriptive statistics

\begin{tabular}{|c|c|c|c|c|c|c|c|c|c|c|c|c|}
\hline & \multicolumn{3}{|c|}{ Food } & \multirow[b]{2}{*}{ Max } & \multicolumn{4}{|c|}{ Traditional sector } & \multicolumn{4}{|c|}{ Total manufacturing } \\
\hline & Mean & Std. Dev. & Min & & Mean & Std. Dev. & Min & Max & Mean & Std. Dev. & Min & Max \\
\hline Inno & 0.615 & 0.487 & 0 & 1 & 0.634 & 0.482 & 0 & 1 & 0.671 & 0.470 & 0 & 1 \\
\hline $\operatorname{lnEMP}$ & 3.351 & 0.949 & 1.099 & 6.075 & 3.472 & 0.965 & 1.099 & 6.750 & 3.519 & 1.010 & 1.099 & 6.873 \\
\hline $\ln K$ & 14.259 & 1.493 & 9.931 & 17.935 & 13.607 & 1.666 & 8.927 & 17.973 & 13.597 & 1.698 & 8.927 & 17.973 \\
\hline $\mathrm{RD}$ & 1.145 & 7.302 & 0 & 121.393 & 1.756 & 15.615 & 0 & 603.290 & 1.825 & 13.261 & 0 & 603.290 \\
\hline $\operatorname{lnCL}$ & 10.179 & 0.879 & 3.795 & 14.288 & 10.153 & 0.727 & 2.954 & 15.884 & 10.228 & 0.717 & 2.954 & 15.884 \\
\hline Age & 31.472 & 26.140 & 0 & 146 & 27.137 & 21.976 & 0 & 256 & 27.823 & 22.680 & 0 & 256 \\
\hline North & 0.565 & 0.497 & 0 & 1 & 0.673 & 0.469 & 0 & 1 & 0.719 & 0.450 & 0 & 1 \\
\hline Uni_TT & 1.765 & 3.697 & 0 & 16.868 & 2.286 & 4.332 & 0 & 16.868 & 3.114 & 5.305 & 0 & 16.868 \\
\hline Uni_Patents & 12.492 & 25.822 & 0 & 117 & 14.555 & 29.531 & 0 & 117 & 20.792 & 37.015 & 0 & 117 \\
\hline Spinoff & 1.286 & 2.763 & 0 & 12 & 1.826 & 3.284 & 0 & 12 & 2.387 & 3.910 & 0 & 12 \\
\hline Uni_Quality & 1.036 & 1.310 & 0 & 5.374 & 1.037 & 1.362 & 0 & 5.374 & 1.239 & 1.484 & 0 & 5.374 \\
\hline Aggl & 1.004 & 0.329 & 0.437 & 1.652 & 1.158 & 0.366 & 0.437 & 3.081 & 1.139 & 0.333 & 0.437 & 3.081 \\
\hline Patents & 0.878 & 0.724 & 0 & 3.1 & 1.102 & 0.690 & 0 & 3.1 & 1.196 & 0.712 & 0 & 3.1 \\
\hline Uni_TTOther & 0.797 & 0.355 & 0.209 & 1.841 & 0.921 & 0.321 & 0.209 & 1.841 & 0.927 & 0.316 & 0.209 & 1.841 \\
\hline Uni_PatentsOther & 5.349 & 2.100 & 1.558 & 10.353 & 6.014 & 1.862 & 1.558 & 11.288 & 6.002 & 1.862 & 1.558 & 11.288 \\
\hline Uni_SpinoffOther & 0.615 & 0.309 & 0.136 & 1.369 & 0.714 & 0.270 & 0.136 & 1.369 & 0.722 & 0.266 & 0.136 & 1.369 \\
\hline Uni_QualityOther & 0.447 & 0.138 & 0.182 & 0.809 & 0.487 & 0.126 & 0.182 & 0.872 & 0.488 & 0.122 & 0.182 & 0.872 \\
\hline $\mathrm{N}^{\circ}$ of obs. & \multicolumn{3}{|c|}{301} & & \multicolumn{2}{|c|}{1819} & & & \multicolumn{2}{|c|}{3719} & & \\
\hline
\end{tabular}


Table A3. Correlation matrix

\begin{tabular}{|c|c|c|c|c|c|c|c|c|c|c|c|c|c|c|c|c|c|}
\hline & Inno & $\operatorname{lnEMP}$ & $\ln K$ & $\mathrm{RD}$ & $\operatorname{lnCL}$ & Age & $\begin{array}{l}\text { Uni_ } \\
\text { TT }\end{array}$ & $\begin{array}{l}\text { Uni_ } \\
\text { Patents }\end{array}$ & Spinoff & $\begin{array}{l}\text { Uni__ } \\
\text { Quality }\end{array}$ & Aggl & Patents & North & $\begin{array}{l}\text { Uni_TT } \\
\text { Other }\end{array}$ & $\begin{array}{l}\text { Uni_ } \\
\text { Patents } \\
\text { Other }\end{array}$ & $\begin{array}{l}\text { Uni_- } \\
\text { Spinoff } \\
\text { Other }\end{array}$ & $\begin{array}{l}\text { Uni_ } \\
\text { Quality } \\
\text { Other }\end{array}$ \\
\hline Inno & 1 & & & & & & & & & & & & & & & & \\
\hline $\operatorname{lnEMP}$ & 0.1881 & 1 & & & & & & & & & & & & & & & \\
\hline $\ln K$ & 0.1621 & 0.6396 & 1 & & & & & & & & & & & & & & \\
\hline $\mathrm{RD}$ & 0.0429 & -0.0021 & -0.0727 & 1 & & & & & & & & & & & & & \\
\hline $\operatorname{lnCL}$ & 0.0853 & 0.0647 & 0.3579 & -0.1289 & 1 & & & & & & & & & & & & \\
\hline Age & 0.0824 & 0.2391 & 0.229 & -0.024 & 0.1339 & 1 & & & & & & & & & & & \\
\hline Uni_TT & 0.0204 & -0.0312 & -0.0748 & -0.0071 & 0.0941 & 0.13 & 1 & & & & & & & & & & \\
\hline Uni_Patents & 0.0195 & -0.0205 & -0.0606 & -0.0056 & 0.0946 & 0.1269 & 0.9696 & 1 & & & & & & & & & \\
\hline Spinoff & 0.017 & -0.0292 & -0.0745 & -0.0121 & 0.0947 & 0.1264 & 0.9634 & 0.9037 & 1 & & & & & & & & \\
\hline Uni_Quality & 0.0201 & -0.0147 & -0.0631 & 0.0005 & 0.061 & 0.1009 & 0.7279 & 0.7251 & 0.6728 & 1 & & & & & & & \\
\hline Aggl & 0.0469 & 0.0144 & -0.0644 & 0.0156 & 0.059 & 0.0173 & -0.1417 & -0.199 & -0.1093 & -0.2801 & 1 & & & & & & \\
\hline Patents & 0.0121 & 0.025 & -0.0723 & 0.021 & 0.1119 & 0.1299 & 0.4186 & 0.3901 & 0.441 & 0.3943 & 0.3213 & 1 & & & & & \\
\hline North & -0.006 & 0.0454 & -0.0096 & -0.0055 & 0.1286 & 0.1378 & 0.1699 & 0.1719 & 0.2228 & 0.0037 & 0.1774 & 0.6284 & 1 & & & & \\
\hline Uni_TTOther & 0.0241 & 0.0107 & -0.042 & -0.0007 & 0.0853 & 0.0543 & -0.2478 & -0.2765 & -0.237 & -0.3338 & 0.5963 & 0.4212 & 0.46 & 1 & & & \\
\hline $\begin{array}{l}\text { Un1_Patents } \\
\text { Other } \\
\text { Uni_Spinoff }\end{array}$ & 0.0178 & 0.0232 & -0.0222 & -0.0022 & 0.068 & 0.0396 & -0.3603 & -0.3903 & -0.3366 & -0.4288 & 0.5552 & 0.3507 & 0.4943 & 0.9622 & 1 & & \\
\hline $\begin{array}{l}\text { Other } \\
\text { Uni__Quality }\end{array}$ & 0.0254 & 0.0151 & -0.0413 & 0.0043 & 0.089 & 0.062 & -0.234 & -0.2611 & -0.2325 & -0.2932 & 0.5859 & 0.4641 & 0.5023 & 0.9842 & 0.9476 & 1 & \\
\hline Other & 0.0412 & 0.0054 & -0.0576 & 0.005 & 0.0682 & 0.0144 & -0.1409 & -0.1681 & -0.1372 & -0.3238 & 0.689 & 0.3921 & 0.2951 & 0.8578 & 0.8044 & 0.8425 & 1 \\
\hline
\end{tabular}




\section{REFERENCES}

Acosta, M., Coronado, D., Toribio, M.R., 2011. The use of scientific knowledge by Spanish agrifood firms. Food Policy 36 (4), 507-516.

Acs Z. J., Audretsch D. B., Feldman M. P., 1992. Real Effects of Academic Research: Comment. The American Economic Review, 82: 363-367.

Aldieri L., Cincera M. , 2009. Geographic and technological R\&D spillovers within the triad: Micro evidence from US patents. The Journal of Technology Transfer. 34, 196-211.

Alfranca O., Rama R., von Tunzelmann N., 2003. Technological fields and concentration of innovation among food and beverage multinationals, International Food and Agribusiness Management Review , 5, 2, 1- 14.

Alfranca O., Rama R., von Tunzelmann, N., 2002. A patent analysis of global food and beverage firms: the persistence of innovation. Agribusiness 18, 349-368.

Anselin L., Varga A., Acs Z., 1997. Local geographic spillovers between university research and high technology innovations. Journal of Urban Economics, 42: 422-448.

Arias-Aranda D., Romerosa-Martínez M.M., 2010. Innovation in the functional foods industry in a peripheral region of the European Union: Andalusia (Spain). Food Policy 35, 240-246:

Arrow K., 1962. The economic implications of learning by doing. Review of Economic Studies 29, $155-172$.

Arvanitis S., Sydow N., Woerter M., 2008. Is there any impact of university-industry knowledge transfer on innovation and productivity? - An empirical analysis based on Swiss firm data. Review of Industrial Organization, 32: 77-94.

Audretsch D.B., Hülsbeck, M.. Lehmann E.E., 2012. Regional competitiveness, university spillovers, and entrepreneurial activity. Small Business Economics, 39:587-601.

Audretsch D.B., Feldmann M.P., 2004. Knowledge Spillovers and the Geography of Innovation. Handbook of Regional and Urban Economics. 4, 2713-2739.

Audretsch D. B., Feldman M. P., 1996. R\&D spillovers and the geography of innovation and production, American Economic Review, 86, 630-640.

Autant-Bernard C. , 2001. Science and knowledge flows: evidence from the French case. Research Policy, 30: 1069-1078. 
Autant-Bernard C. , 2012. Spatial Econometrics of Innovation: Recent Contributions and Research Perspectives. Spatial Economic Analysis. 7 (4): 403-419.

Avermaete T., Viaene J., Morgan E. J., Pitts E., Crawford N. Mahon D., 2004. Determinants of product and process innovation in small food manufacturing firms. Trends in Food Science \& Technology, 15, 10: 474-483.

Banterle A., Cavaliere A., Carraresi L., Stranieri S., 2011. Innovativeness in food small business: What is its relationship with marketing? Agricultural Economics -AGRICECON, 57(10), 74-483, ISSN 0139-570X.

Baregheh A. Rowley J., Sambrook S., Davies D., 2012. Innovation in food sector SMEs. Journal of Small Business and Enterprise Development, 19, 2: 300-321.

Belderbos R., Carree M., Lokshin B., 2004. Cooperative R\&D and firm performance. Research Policy,33, 1477-1492.

Bergman E. M., 2010,. Knowledge links between European universities and Forms: A review, Papers in Regional Science, 89, 2, 311-333

Blind K., Grupp H., 1999. Interdependencies between the science and technology infrastructure and innovation activities in German regions: empirical findings and policy consequences. Research Policy, 28: 451-468.

Bodas Freitas I.M., Marquesc R.A., Mirra de Paula, Silva E. 2013, University-industry collaboration and innovation in emergent and mature industries in new industrialized countries, Research Policy, 42, 443- 453.

Botazzi, L., Peri, G., 2003. Innovation and spillovers in regions: Evidence from European patent data. European Economic Review. 47: 687-710.

Capitanio F, Coppola A., Pascucci S., 2010. Product and Process Innovation in the Italian Food Industry, Agribusiness, Vol. 26 (4) 503-518.

Cardamone P., Pupo V. and Ricotta F. , 2015. University Technology Transfer and Manufacturing Innovation: The Case of Italy. Review of Policy Research, 32: 297-322.

Carew R., 2005. Science policy and agricultural biotechnology in Canada. Review of Agricultural Economics 27, 300-316.

Chaudhry Q., Castle L, 2011. Food applications of nanotechnologies: An overview of opportunities and challenges for developing countries, Trends in Food Science \& Technology 22, 595- 603. 
Christensen J. L., Rama R., von Tunzelmann N., 1996. Study on innovation in the European Food Products and Beverages Industry: 145. EIMS/SPRINT Brussels: The European Commission.

CIAA, 2014. Data \& Trends of the European Food and Drink Industry 2013-2014. Confederation of the food and drink industries of the EU. URL: www.ciaa.be.

(http://www.fooddrinkeurope.eu/S=0/publication/data-trends-of-the-european-food-and-drinkindustry-2013-2014/)

De Jong J. P., Vermeulen P. A., 2006. Determinants of Product Innovation in Small Firms A Comparison Across Industries. International Small Business Journal, 24, 6: 587-609.

Del Barrio-Castro T. , García-Quevedo J., 2005. Effects of university research on the geography of innovation. Regional Studies, 39, 9: 1217-1229.

Döring T. , Schnellenbach J., 2006. What do we know about geographical knowledge spillovers and regional growth?: A survey of the literature, Regional Studies, 40:03, 375-395.

Drukker D. M., H. Peng I. R. Prucha, Raciborski R., 2013. Creating and managing spatialweighting matrices with the spmat command. Stata Journal 13: 242-286.

Eom B.-Y. , Lee K.. 2010. Determinants of industry-academy linkages and, their impact on firm performance: The case of Korea as a latecomer in knowledge industrialization. Research Policy, 39: 625-639.

European Commission, 2008. Science, technology and innovation in Europe. Luxemburg: Office for Official Publications of the European Communities.

European Commission, 2010. EUROPE 2020. A strategy for smart, sustainable and inclusive growth, Brussels, 3.3.2010.

European Commission, Directorate-General for Enterprise and Industry, 2014. Reindustrialising Europe. Member States' Competitiveness Report 2014, Luxembourg.

Foray D., Lissoni F. , 2010. University research and public-private interaction, Handbooks in Economics, Volume 1, 275-314, Elsevier B.V.

Fritsch M., Franke, G., 2004. Innovation, regional knowledge spillovers and R\&D co-operation. Research Policy, 33, 245-255.

Galizzi G., Venturini L., 1996. Product innovation in the food industry: nature, characteristics and determinants. In: Galizzi, G., Venturini, L. (Eds.), Economics of Innovation: The Case of Food Industry. Physica-Verlag, Heidelberg, pp. 133-153. 
García Martinez M., Burns, J., 1999. Sources of Technological Development in the Spanish Food \& Drink Industry. A 'Supplier-Dominated' Industry'. Agribusiness: An International Journal. Agribusiness, 15 (4): 431-448.

Giuliani E., Arza V., 2009. What drives the formation of 'valuable' university-industry linkages? Insights from the wine industry, Research Policy, 38, 906-921.

Grimpe C., Sofka W., 2009. Search patterns and absorptive capacity: a comparison of low- and high-technology firms from thirteen European countries', Research Policy 38 495-506

Grunert K.G., Harmsen H., Meulenberg, M., Kuiper, E., Ottowitz, T., Declerc, F., Traill, W.B., Göransson, G., 1997. A framework for analysing innovation in the food sector. In: Traill, W.B., Grunert, K.G. (Eds.), Product and Process Innovation in the Food Industry. Blackie Academic \& Professional, London, pp. 1-37.

Hirch S., Schiefer J., Gschwandtner A., Harmann M., 2013. Profit persistence in the food industry: evidence from five European countries. European Review of Agricultural Economics, 40(5), 741759 ,

Hirsch-Kreinsen H., 2008. "Low-Technology”: A Forgotten Sector In Innovation Policy, J. Technol. Manag. Innov., 3, 3, 11-20.

Hirsch-Kreinsen, H., Jacobson, D., Robertson, P. , 2006. Low-tech industries: Innovativeness and development perspectives. A summary of a European research project. Prometheus, 24, 3-21

Huiban J.P., Bouhsina Z., 1998. Innovation and the quality of labour factor: an empirical investigation in the French food industry. Small Business Economics 10, 389-400.

ISTAT (2008), La Ricerca e Sviluppo in Italia - Anno 2006, Statistiche in breve, Rome.

Italian National Statistics Institute [ISTAT]. 2014, Struttura e dimensione delle imprese - Archivio statistico delle imprese attive. Anno 2012. http://www.istat.it/it/archivio/131578.

Jaffe A. B., 1989. Real Effects of Academic Research. The American Economic Review, 79: 967970.

Menrad K., 2004. Innovations in the food industry in Germany, Research Policy, 33, 845-878.

Kinsey J.D., 2001. The new food economy: consumers, farms, pharms, and science. American Journal of Agricultural Economics 83 (5), 1113-1130.

Koo J., 2005. Technology Spillovers, Agglomeration, and Regional Economic Development. Journal of Planning Literature. 20, 99-115. 
Laursen K., and Salter, A., 2004. Searching high and low: what types of firms use universities as a source of innovation? Research Policy, 33, 8, 1201- 1215.

Laursen K., Reichstein, T, Salter, A. 2011. Exploring the Effect of Geographical Proximity and University Quality on University-Industry Collaboration in the United Kingdom. Regional Studies, 45 (4), 507-523.

Leten B., Landoni P., Van Looy B., 2011. Developing Technology in the Vicinity of Science: Do Firms Benefit? An Overview and Empirical Assessment on the Level of Italian Provinces, in Science and Innovation Policy for the New Knowledge Economy, PRIME Series on Research and Innovation Policy in Europe, Edited by Massimo G. Colombo, Luca Grilli, Lucia Piscitello and Cristina Rossi-Lamastra.

Lööf H., Broström,A., 2008. Does knowledge diffusion between university and industry increase innovativeness? J Technol Transfer, 33, 73-90

Maietta O.W., 2015. Determinants of university-firm R\&D collaboration and its impact on innovation: A perspective from a low-tech industry, Research Policy 44, 1341-1359

Monducci R., 2011. Innovazione e competitività delle imprese dell'industria alimentare, Paper presented in: L'innovazione tecnologica come leva di competitività per l'industria alimentare, CIBUS TEC Workshop- Parma, 18 October 2011.

Monjon S., Waelbroeck P., 2003. Assessing spillovers from universities to firms: evidence from French firm-level data. International Journal of Industrial Organization, 21: 1255-1270.

Najib M. , Kiminami A., 2011. Innovation, cooperation and business performance: Some evidence from Indonesian small food processing cluster. Journal of Agribusiness in Developing and Emerging Economies, 1, 1: 75-96.

Piergiovanni R., Santarelli E., Vivarelli M., 1997. From which source do small firms derive their innovative inputs? Some evidence from Italian industry. Review of Industrial Organization, 12: 243-258.

Ponds R., van Oort F., Frenken K., 2010. Innovation, spillovers and university-industry collaboration: an extended knowledge production function approach. Journal of Economic Geography, 10: 231-255.

Rama R., 1996. An empirical study on sources of innovation in the international Food and Beverage industry. Agribusiness: An International Journal, 12: 123-134. 
Rama R., Von Tunzelmann, N., 2008 "Empirical studies of innovation in the food and beverage industry", in Rama, R. (Ed.), Handbook of Innovation in the Food and Drink Industry, Haworth Press, New York, NY.

Robertson P., Smith K. , von Tunzelman N. 2009. Innovation in low- and medium - technology industries. Research Policy. 38, p. 441-446.

Robin S., Schubert T, 2013. Cooperation with public research institutions and success in innovation: Evidence from France and Germany, Research Policy, 42, 149- 166.

Sarkar S., Costa, A.I.A., 2008. Dynamics of open innovation in the food industry. Trends in Food Science \& Technology 19, 574-580.

Smit M.J., Abreu M.A. , de Groot H. L.F. , 2013. Micro-evidence on the Determinants of Innovation in the Netherlands: The Relative Importance of Absorptive Capacity and Agglomeration Externalities. Papers in Regional Science. DOI: 10.1111/pirs.12068.

Triguero A., Córcoles D., Cuerva M. C., 2013. Differences in Innovation Between Food and manufacturing Firms: An analysis of Persistence, Agribusiness, 29(3), 273-292.

Welch R.W., Mitchell P.C., 2000. Food processing: a century of change. British Medical Bulletin $56(1), 1-17$. 